\title{
The O'Brien defence refined: legal rights, equitable wrongs and commercial responsibilities
}

\author{
Michael Haley
}

Keele University

The prevalence of home ownership has inevitably ensured that the family home 1 is exploited as security for the raising of additional finance. As the Law Commission acknowledged:

It is, in many cases, the single most valuable asset of its owner. It has great economic significance as a means of securing capital advances by way of loan and of recovering debts owed. ${ }^{1}$

This emphasis upon the home as property entails that it has a dual role to play, that is to provide a setting within which family life can be enacted and to afford a significant capital asset. $^{2}$ While in the majority of cases these two functions coexist well, major difficulties are likely to emerge when a creditor elects to enforce its security in the family home. A commonplace scenario arises where, say, one co-owner is in business and the other has offered the home as security for a loan or other financial facility for that business. The latter co-owner is, thereby, acting as a mere guarantor for the former. ${ }^{3}$ If matters then go awry, the divergence between the respective interests of the homeowner and the lender becomes stark.

This tension was recognised by Lord Nicholls in Royal Bank of Scotland plc $\mathrm{v}$ Etridge (No 2) who cautioned against the court taking an overly paternalistic approach, "Their home is their property. The law should not restrict them in the use they make of it." 4 This sourcing of finance is, moreover, heavily dependent upon lenders having the confidence that, if the need arises, the security will be enforceable against all signatories to the charge. Nevertheless, within the family sphere this type of surety relationship offers scope for undue influence, misrepresentation, duress and other wrongdoing. In a time of economic recession, the risk factor associated with such ventures is, undeniably, heightened. Lord Nicholls warned that, "The law would be seriously defective if it did not recognise these realities." 5 The difficulty, of course, is how to cast a fair and workable test that manages to

1 Sharing Homes: A discussion paper, Law Comm. No 278 (2002), at para. 1.8.

2 Lord Nicholls explained in Royal Bank of Scotland plc v Etridge (No 2) [2001] 4 All ER 449 at 463 : "Finance raised by second mortgages on the principal's home is a significant source of capital for the start-up of small businesses." Lord Bingham agreed that such transactions are "of great social and economic importance" (at 456).

3 For example, as occurred in Barclays Bank v O'Brien [1993] 4 All ER 417 and the eight conjoined appeals in Royal Bank of Scotland plc v Etridge (No 2) [2001] 4 All ER 449.

4 Ibid., at 463.

5 Ibid. 
preserve the commercial interests of institutional lenders while maintaining a roof over the head of a vulnerable homeowner. The solution sponsored by the House of Lords in both the O'Brien and Etridge litigation focused upon the application of the doctrine of notice. ${ }^{6}$ The surety's claims will, therefore, prevail over the rights of any creditor who had actual, constructive or imputed notice of the wrongdoing of the principal debtor. ${ }^{7}$ Conversely, the bona fide purchaser without notice enjoys a good defence to the surety's claim. ${ }^{8}$ Although the doctrine of notice represents a tried and tested means of determining liability between competing claimants, it is not a universal curative. ${ }^{9}$ Lord Nicholls admitted that, "Like every compromise, the outcome falls short of achieving in full the objects of either of the two competing interests." 10

This judicial balancing act must be sensitive to shifts in social policy and changes in banking practices. The responsive nature of this jurisdiction was demonstrated clearly by the House of Lords in the Etridge case where a fundamental overhaul of the pre-existing law was undertaken. First, the House recast the role of undue influence and, in particular, provided a thorough and authoritative narrative as to the evidential presumptions that drive what has to be proved and by whom. It is most regrettable that these reforms appear not to have been fully absorbed and that, as Mummery LJ lamented, "fundamental misconceptions persist". ${ }^{11}$ The need for a wider appreciation of the role of undue influence and the nature of its attendant evidential presumptions remains obvious. The present article aims to address this issue.

Secondly, the structure of the O'Brien test was remodelled so as to strengthen the safeguards available to the surety and, with the concept of constructive notice in mind, to demand more of both the lender and the independent advisor in the transactional process. As the compromise is necessarily defined in expansive terms, it continues to be tested and adapted according to the multifactorial situations that arise and drive litigation. ${ }^{12}$ This is particularly so with the shield afforded by independent legal advice. While the prescription as to what lawyers must do in the discharge of their professional duties to surety clients is relatively clear, the range of circumstances within which an advisor's professional incompetence and lack of integrity will affect the lender remains an issue for debate. The present work will chart the evolutionary process of this jurisdiction and evaluate the current parameters of the O'Brien compromise.

\section{Myth and misunderstanding}

It is undeniable fact that the majority of disputes concern the relationship between husband and wife. The authorities seemingly demonstrate that wives are more likely than others to leave the management of joint financial affairs to another (i.e. the husband). The sexual and emotional ties between spouses provide a ready opportunity for the exertion of undue influence. The informality of business dealings between them increases the potential for misrepresentation as to the true nature of the financial enterprise. The scope for abuse,

6 This was not, however, a novel idea and had been canvassed previously in De Lisle v Union Bank of Scotland [1914] 1 Ch 22.

7 Lancashire Loans Ltd v Black [1934] 1 KB 380.

8 Bainbrigge $\mathrm{v}$ Browne (1881) 18 Ch D 188.

9 Nor is registered land an orthodox setting for its operation: see G Battersby (1995) 15 Legal Studies 35 and the views expressed by Lewison J in Thompson v Foy [2010] 1 P \& CR 16.

10 Royal Bank of Scotland plc v Etridge (No 2) [2001] 4 All ER 449 at 463.

11 Niersmans v Pesticcio [2004] EWCA Civ 372 at [2].

12 Incredibly, there are still instances of lenders doing absolutely nothing to protect their interests against the possible claims of a surety: see Hewett v First Plus Financial Group [2010] EWCA Civ 312. 
however, extends well beyond this brand of familial relationship. As Lord Nicholls observed, "there is no rational cut-off point, with certain types of relationship being susceptible to the O'Brien principles and others not". ${ }^{13}$ Victims have, for example, included aged mothers, ${ }^{14}$ elderly and illiterate fathers, ${ }^{15}$ delusional daughters, ${ }^{16}$ vulnerable girlfriends, ${ }^{17}$ gullible cohabitants, ${ }^{18}$ impressionable employees, ${ }^{19}$ mentally impaired exboxers $^{20}$ and naive singer-songwriters. ${ }^{21}$

While at common law the contractual bargain was effectively sacrosanct, ${ }^{22}$ equity evolved a broader jurisdiction under which a bargain between a surety and a creditor could be overturned as a result of the equitable wrongdoing of the principal debtor. The origins of this tender approach are accredited to the decision of the Privy Council in Turnbull \& Co. v Duval. ${ }^{23}$ There it was held that, even though the creditor did not have actual notice of any wrongdoing, the security given by Mrs Duval could not be upheld. Although this outcome could have been based solely upon the finding of a breach of fiduciary duty, ${ }^{24}$ Lord Lindley felt that there was an even stronger ground for impeaching the transaction:

Mrs Duval was pressed by her husband to sign, and did sign, the document, which was very different from what she supposed it to be, and a document of the true nature of which she had no conception. It is impossible to hold that Campbell or Turnbull \& Co. are unaffected by such pressure and ignorance. They left everything to Duval, and must abide the consequences. ${ }^{25}$

The facts of Duval shed little light on the reasoning underpinning this interventionist stance and it is unclear exactly what legal or equitable wrong (if any) the husband committed. Although mention is made of pressure and concealment of material facts, there was no allegation of misrepresentation or undue influence pleaded and no finding by the court that such wrongdoing had been perpetrated. Lord Browne-Wilkinson was bemused:

It is impossible to find a sound basis for holding that Mrs Duval was entitled to set aside the transaction as against her husband. How then could she set it aside as against Turnbulls?26

In such circumstances, it must be for the surety to satisfy him or herself as to the nature and extent of the obligations undertaken. ${ }^{27}$ Hence, Lord Browne-Wilkinson admitted of the Privy Council's conclusion, "I can only assume that . . it proceeded on a mistaken basis." 28

13 Royal Bank of Scotland plc v Etridge (No 2) [2001] 4 All ER 449 at 475.

14 National Westminster Bank plc v Amin [2002] 1 FLR 735.

15 Portman Building Society v Dusangh (2000) Lloyds Rep Bank 197.

16 Public Trustee v Bailey [2005] EWHC 3524 (Ch).

17 Burbank Securities v Wong [2008] EWHC 552 (Ch).

18 Butigan v Negus-Fancy (2000) EG 67 (CS).

19 Credit Lyonnais Bank v Burch [1997] 1 All ER 144.

20 Shaw v Finnemore [2009] EWHC 367 (Ch).

21 Wadlow v Samuel [2006] EWHC 1492 (QB).

22 It could, however, be overturned within the limited parameters of misrepresentation, duress and mistake.

23 [1902] AC 429.

24 Turnbull's manager (Mr Campbell) also acted as a trustee of an estate under which Mrs Duval was a beneficiary.

25 [1902] AC 429 at 435.

26 Barclays Bank v O’Brien [1993] 4 All ER 417 at 426.

27 It is to be appreciated that, "An adult of competent mind is entitled to enter into a financially unwise transaction if he or she wants to": per Lewison J in Thompson v Foy [2010] 1 P \& CR 16 at [99].

28 Barclays Bank v O'Brien [1993] 4 All ER 417 at 426. The law will generally expect a signatory to a document to act responsibly and carefully so that he or she will understand the general effect of what is being signed: Saunders v Anglia Building Society [1971] AC 1004. 
Even if wrongdoing by the husband had been established, the fundamental problem remains that the Privy Council failed to explain why the security became unenforceable simply because the creditor entrusted Mr Duval to obtain his wife's signature. The outcomedriven approach of the Privy Council is shrouded in mystery and various attempts to justify the decision have proved spectacularly unsuccessful. Lord Browne-Wilkinson observed: "Like most law founded on obscure and possibly mistaken foundations it has developed in an artificial way, giving rise to artificial distinctions and conflicting decisions." ${ }^{29}$ First, the Duval decision has been appraised in terms that the relationship of husband and wife automatically gives to a presumption of undue influence. ${ }^{30}$ This quite clearly is bad law as, for these purposes, there is nothing special or unique about this type of relationship. ${ }^{31}$

Secondly, it has been argued that the result was achieved due to a shift in the burden of proof that occurs when a wife makes a substantial voluntary disposition. ${ }^{32}$ This is also unsound law. It is patently unrealistic to require the lender to prove affirmatively that the surety fully understood the transaction and entered it of her own free will. ${ }^{33}$

Thirdly, the decision has been appraised on the basis that some form of "special equity" arises whenever a wife stands as surety for her husband. ${ }^{34}$ This existence of such a special equity would entail that, provided the lender is aware of the connubial ties, it must take appropriate steps to ensure that the wife fully understands the nature of the bargain. ${ }^{35}$ The special equity approach was, unsurprisingly, rejected by the House in the O'Brien case. The creditor cannot be expected to advise its customers as to the wisdom of a proposed transaction. ${ }^{36}$ Indeed, to require this would be to place a greater duty on the lender than lies with the wrongdoer.

Fourthly, and most commonly, it was thought that the outcome was rooted in some "special agency" that existed between the husband and the creditor. ${ }^{37}$ This was notwithstanding the fact that there was no allusion to agency in the Duval decision and that Mr Duval was throughout acting for himself. This type of agency was, indeed, "special" as there was no requirement for any actual or ostensible authority to be given to the agent. ${ }^{38}$ Instead, the relationship arose solely because the lender entrusted the debtor to obtain the surety's signature. ${ }^{39}$ It would not, therefore, arise where the lender relied on a third party to procure the signature. ${ }^{40}$ Once the agency was invoked, the principal could not be in a better position than the husband. The agent's misfeasance, thereby, became the principal's misfeasance. ${ }^{41}$ The special agency theory was also laid to rest in the O'Brien case. It can no

29 Barclays Bank v O'Brien [1993] 4 All ER 417 at 428.

30 Bishoff's Trustee v Frank (1903) 89 LT 188.

31 Bank of Montreal v Stuart [1911] AC 120.

32 Hoghton $\mathrm{v}$ Hoghton (1852) 15 Beav 278. Hence, the creditor would need to establish that the transaction was freely entered into with a full awareness.

33 Barclays Bank v O’Brien [1993] 4 All ER 417.

34 Yerkey v Jones (1939) 63 CLR 649.

35 This approach was sponsored by Scott LJ in the Court of Appeal in Barclays Bank v O'Brien [1992] 4 All ER 983.

36 Redmond v Allied Irish Banks [1987] 2 FTLR 264.

37 In Avon Finance Co Ltd v Bridger [1985] 2 All ER 281, this was extended to the relationship between the lender and the surety's son.

38 Barclays Bank plc v Kennedy (1989) P \& CR 221.

39 Chaplin \& Co. Ltd v Brammall [1908] KB 233.

40 Midland Bank plc v Perry (1988) 56 P \& CR 202; Collundell Ltd v Gallon [1986] 2 WLR 466.

41 Kings North Trust v Bell [1986] 1 WLR 119. 
longer be argued that some form of agency arises from the creditor merely requiring the husband to obtain the wife's signature as a condition of the loan. ${ }^{42}$

Accordingly, it fell to the House of Lords in Barclays Bank v O'Brien ${ }^{43}$ to justify this interventionist jurisdiction and to distil principle from the uncertainty that had previously dogged its existence. The mechanics of the test propounded by Lord Browne-Wilkinson are expansive, but represent a familiar and convenient approach to the resolution of spousal surety disputes. The jurisdiction is founded upon the premise that a person who has been induced by the legal wrongdoing of the debtor to stand as surety enjoys an equity against the wrongdoer to set aside the transaction. If there is no wrongdoing, there is nothing that can taint the transaction. This is because the purpose of equitable intervention is to protect an individual from victimisation by another and not to protect persons from their own folly. ${ }^{44}$ Such wrongdoing can affect the creditor who is put on inquiry by the fact that the transaction is not a conventional joint advance and, therefore, should suspect that some wrongdoing may be afoot. Understandably, if the transaction appears to the lender to be a normal joint transaction there is no reason why such warning bells will be sounded. The creditor once on inquiry will then have constructive notice of the wrongdoing unless it takes reasonable steps to ensure that the surety's consent is properly obtained.

The use of the doctrine of notice to determine priority between conflicting property claims is well established and eminently workable. It is without doubt preferable to any of the alternative theories previously sponsored. Nevertheless, it remains impossible to ensure that a surety is entirely liberated from undue influence. All the law can do is, as Lord Bingham put it, "indicate minimum requirements which, if met, will reduce the risk of error, misunderstanding or mishap to an acceptable level". 45 The broad-brush approach adopted by Lord Browne-Wilkinson merely laid out the schematics of the new jurisprudence, leaving it to be incrementally adapted and refined by subsequent authorities, of which there were to be many. ${ }^{46}$

\section{Establishing undue influence}

Although the facts of the O'Brien case concerned a misrepresentation made by a husband to his wife concerning the extent of financial liability undertaken, it was the law relating to undue influence that attracted detailed attention. ${ }^{47}$ This is not surprising as undue influence has fuelled the majority of the litigation in this area and, due to its insidious nature, can be notoriously difficult to prove. ${ }^{48}$ In order to combat the problem, and as will become clear, the law recognises that undue influence can, in certain situations, be presumed with a

42 Bradford \& Bingley Building Society v Chandock (unreported) 3 April 1996.

43 [1993] 4 All ER 417. Lord Hobhouse in Royal Bank of Scotland plc v Etridge (No 2) [2001] 4 All ER 449 at 479 appraised Lord Browne-Wilkinson's speech as, "a masterly exposition of principles".

44 Allcard v Skinner (1837) 36 Ch D 145. In Greenwood Forest Products (UK) Ltd v Roberts (unreported) 12 March 2010, Deputy Judge Stephen Morris explained, at [265]: "Mr Roberts entered into the Arrangements on the basis of his own independent and informed judgment. Regardless of whether that judgment was wise or sound, it was nevertheless his judgment."

45 Royal Bank of Scotland plc v Etridge (No 2) [2001] 4 All ER 449 at 456 . The provision of information will usually offer an effective counterweight to misrepresentation.

46 Lord Hobhouse observed in Royal Bank of Scotland plc v Etridge (No 2) [2001] 4 All ER 449 at 479: "Experience in litigation since 1993 has not been encouraging. Disputes have continued to come before the courts; the determination of those disputes has not always carried conviction."

47 Mrs O'Brien signed the documentation because she was persuaded that it was the right thing to do. There was no pressure exerted by her husband that deprived her of the ability to give her consent freely.

48 NI Yaakub and A McGee state in "Undue influence in bank lending transactions: confusions continue" (2007) JIBLR 394, at 397, that, "undue influence is an obscure and difficult principle". 
resultant shift in the burden of proof. ${ }^{49}$ There are two presumptions available. The first concerns what may be described as a presumption at law of "influence" where the relationship between the parties falls within specified categories. The second presumption is purely evidential and arises when a relationship of trust and confidence is established and it is shown that the transaction demands explanation. The burden then shifts and the alleged wrongdoer must establish that the transaction was not generated by undue influence. If this burden is not discharged, it will be presumed that the influence is, indeed, undue. It is the scope for, and operation of, these presumptions that has brought about much confusion and misunderstanding. 50

Undue influence is an equitable defence that looks toward the manner in which the consent to a transaction was produced. ${ }^{51}$ Although undue influence may be described in general terms, it remains immune to precise definition. ${ }^{52}$ As Lord Clyde observed: "It is something which can be more easily recognised when found than exhaustively analysed in the abstract." 53 The defence operates where there is some form of domination, control or other superiority that induces the complainant to enter into a bargain. ${ }^{54}$ Ward LJ explained:

The donor may be led but she must not be driven and her will must be the offspring of her own volition, not a record of someone else's. There is no undue influence unless the donor if she were free and informed could say "This is not my wish but I must do it." 55

The transaction is, therefore, impeachable only if it is generated by unacceptable means. ${ }^{56}$ Accordingly, undue influence carries with it a connotation of impropriety and unconscionable conduct. ${ }^{57}$ It does not, however, have to be shown that the victim made no conscious decision of her own or that her will was totally overborne. ${ }^{58}$

The types of conduct that can amount to undue influence include coercion, domination, victimisation, guileful techniques of persuasion, excessive pressure, emotional blackmail or bullying. Undue influence, moreover, may include fraudulent misrepresentation, which arises where the misstatement is made knowingly or recklessly in the context of a relationship of trust and confidence. ${ }^{59}$ Each constitutes an improper and

49 This evidential gloss does not, however, extend to the defence of misrepresentation, which requires affirmative proof of a false statement of a material fact: Allied Irish Bank v Byrne [1995] 2 FLR 325; Royal Bank of Scotland plc v Chandra [2010] EWHC 105 (Ch).

50 See Sir Martin Nourse in Hammond v Osborn [2002] EWCA Civ 885 at [1].

51 Huguenin $\mathrm{v}$ Basely (1807) 14 Ves 263.

52 See Lord Scarman in National Westminster plc v Morgan [1985] AC 688 at 709.

53 Royal Bank of Scotland plc v Etridge (No 2) [2001] 4 All ER 449 at 477. Lord Nicholls agreed, at 457: "It is impossible to be more precise or definitive. The circumstances in which one person acquires influence over another, and the manner in which influence may be exercised, vary too widely to permit of any more specific criterion."

54 This ascendancy requires more than significant disparity in the bargaining strengths of the parties: Greenwood Forest Products (UK) Ltd v Roberts (unreported) 12 March 2010.

55 Daniel v Drew [2005] EWCA Civ 507 at [36].

56 Castle Phillips Finance v Piddington [1995] 1 FLR 783; Royal Bank of Scotland plc v Chandra [2010] EWHC 105 (Ch). Not all influence, therefore, is undue.

57 See, generally, J Devenney and A Chandler, "Unconscionability and the taxonomy of undue influence" (2007) JBL 541.

58 Hewett v First Plus Financial Group [2010] EWCA Civ 312.

59 UCB Corporate Services Ltd v Williams [2002] EWCA Civ 555. As Lord Nicholls explained in Royal Bank of Scotland plc v Etridge (No 2) [2001] 4 All ER 449 at 463: "Such a husband abuses the influence he has. He fails to discharge the obligation of candour and fairness he owes a wife who is looking to him to make the major financial decisions." 
unacceptable method of persuasion. In Hewett v First Plus Financial Group, ${ }^{60}$ for example, the deliberate failure of the husband to disclose that he was having an affair, and might quit the family home, when his wife acceded to the mortgage amounted to undue influence sufficient to vitiate the transaction. The mere failure to disclose material facts or to explain the transaction, however, will not usually suffice. ${ }^{61}$ As Lord Nicholls put it:

Statements or conduct by a husband which do not pass beyond the bounds of what may be expected of a reasonable husband in the circumstances should not, without more, be castigated as undue influence. ${ }^{62}$

The judicial tendency has long been to compartmentalise undue influence under two generic headings: actual (Class 1) undue influence and presumed (Class 2) undue influence. ${ }^{63}$ These are, as Lewison J pointed out, "no more than different ways of proving the same thing". 64 This is an allusion to the fact that presumed undue influence is proved with the aid of an evidential presumption whereas actual undue influence must be extrinsically proved without the aid of any such presumption. The key to understanding the difference between actual and presumed undue influence lies with the requirement that the parties stand in a relationship of trust and confidence. With Class 1 undue influence, this must be affirmatively proven whereas, with Class 2 undue influence, it can be assumed. While this may appear to be a straightforward distinction, the courts continue to grapple with its operation. This is, as Enonchong warns, "a measure of how deep-seated some of the pre-Etridge misconceptions were. The danger now is that if they are allowed to pass unnoticed they may take root again." 65

Once it is established (whether by implication or otherwise) that there is a relationship of trust and confidence, the next step is for the victim to show that the transaction calls out for explanation. ${ }^{66}$ As demonstrated in Turkey $\mathrm{v}$ Awadh, it is necessary for the court to view the transaction in context, evaluate its general nature and consider what is was intended to achieve for the parties. ${ }^{67}$ On overcoming this hurdle, the burden of proof shifts to the alleged wrongdoer to prove that the relationship of trust and confidence was not abused. ${ }^{68}$ Hence, the combined nature of the relationship and the transaction requires the alleged wrongdoer to justify the bargain and, in particular, to show that the influence did not invade the free volition of the complainant. Most commonly, this will be achieved by demonstrating that the victim had received independent legal advice. ${ }^{69}$ Nevertheless, legal advice is not always decisive of the issue..$^{70}$ The weight or importance of such advice depends on all the circumstances and whether it has an emancipating effect is a question of

60 [2010] EWCA Civ 312.

61 Royal Bank of Scotland plc v Chandra [2010] EWHC 105 (Ch). For these purposes negligence does not equate with fraud: Thompson v Foy [2010] P \& CR 16.

62 Royal Bank of Scotland plc v Etridge (No 2) [2001] 4 All ER 449 at 462, 463.

63 Allcard v Skinner (1887) 36 Ch D 145.

64 [2009] EWHC $1076(\mathrm{Ch})$ at [100].

65 N Enonchong, "Presumed undue influence: continuing misconceptions?" (2005) 121 LQR 29 at p. 33.

66 For example, in Curtis v Pulbrook [2009] EWHC 782 (Ch), Deputy Judge Richard Sheldon stigmatised the transfer in issue as "extremely and manifestly disadvantageous" (at [141]) and felt that it offered "a paradigm case where the presumption of undue influence arises" (at [142]).

67 [2005] 2 P \& CR 29.

68 Roberts v Pascal (unreported) 9 February 2009.

69 Permanent Trustee Co (NSW) Ltd v Bridgewater [1936] 3 All ER 501. In Lancashire Loans Ltd v Black [1934] 1 KB 380 , an argument that a daughter was emancipated by virtue of her marriage from the influence of her mother was roundly rejected.

70 Claughton v Price (1998) 30 HLR 396. 
fact and evidence. ${ }^{71}$ As Lewison J. pointed out, "a person may understand fully the implications of a proposed transaction, for instance, a substantial gift, and yet still be acting under the undue influence of another." 72 Deputy Judge Stephen Morris provided the overview that, if clear and independent legal advice is proffered and understood, "it requires specific and exceptional factors to conclude that the advice did not emancipate the will". ${ }^{73}$

\section{ACTUAL UNDUE INFLUENCE}

Class 1 undue influence requires affirmative proof that the wrongdoer did, indeed, exert undue influence over the victim and that this wrongdoing brought about the entry into the transaction. The complainant must adduce evidence of some improper and unfair conduct, for example, overt persuasion, emotional blackmail, coercion or bullying. ${ }^{74}$ In Bank of $S$ cotland $\mathrm{v}$ Bennett ${ }^{75}$ undue influence arose in circumstances where the wife's will to resist had been broken down by a systematic campaign of wounding and insulting language, demeaning comparisons and an overriding fear that her husband would leave her if she did not comply with his wishes. It must be shown, moreover, that this conduct existed at the date of the impugned transaction. ${ }^{76}$ Subsequent events are relevant only if they, "cast light on what was happening before and at the time of the impugned transaction". ${ }^{77}$

As regards Class 1, there is no need to establish any specific type of antecedent relationship between the parties. It must, however, be positively demonstrated that the nexus between the parties is one of trust and confidence. ${ }^{78}$ Rarely, the necessary tie of trust and confidence may emerge from within the framework of the transaction itself. Such was demonstrated in Macklin v Dowsett where a relationship of ascendancy and dependency arose from a dealing in which the ascendant party knew that the other was in dire financial straits. ${ }^{79}$ More commonly, the nexus will, as Buxton LJ accepted, "spring from a historic relationship between the parties of a general nature that precedes the impugned transaction". ${ }^{80}$ In Credit Lyonnais Bank v Burch, ${ }^{81}$ the relationship of employer and employee had ripened into a relationship of trust and confidence as evidenced by the onerous nature of the transaction entered into by the latter at the request of the employer. A relationship of trust and confidence arose in Inche Noriah v Shaik. Allie Bin Omar where the donor was aged, illiterate and infirm and allowed her nephew to manage the whole of her affairs. ${ }^{82}$ Similarly, in $\mathrm{Re}$ Craig, a sufficiently close relationship emerged between an old and vulnerable man and his secretary companion who managed his affairs. ${ }^{83}$

71 Curtis v Pulbrook [2009] EWHC 782 (Ch).

72 Thompson v Foy [2010] 1 P \& CR 16 at [99]; see also the obiter views of Millett LJ in Credit Lyonnais Bank v Burch [1997] 1 All ER 144 at 156.

73 Greenwood Forest Products (UK) Ltd v Roberts (unreported) 12 March 2010 at [260].

74 Traditionally, a difference between undue influence and duress is that the latter is a narrower defence, requiring the illegitimate exertion of physical force or, at least, the threat of such force: Mutual Finance Ltd v John Wetton \& Sons Ltd [1937] 2 KB 389.

75 (1997) 1 FLR 801.

76 Greenwood Forest Products (UK) Ltd v Roberts (unreported) 12 March 2010.

77 Per Lewison J in Thompson v Foy [2010] 1 P \& CR 16 at [101].

78 In Bank of Scotland v Makris (unreported) 15 May 2009, the parties were close friends and formed part of a business team, with the alleged wrongdoer having the greater expertise in investment matters. Nevertheless, these features did not come close to demonstrating a relationship of trust and confidence.

79 [2004] EWCA Civ 904.

80 Turkey v Awadh [2009] 2 P \& CR 29 at 517.

81 [1997] 1 All ER 144.

82 [1929] AC 127.

83 [1971] Ch 95. 
In addition to establishing that the wrongdoer had the capacity to exert influence over the complainant, it must also be shown that such influence was exerted and was, moreover, undue. ${ }^{84}$ There must also be a causal link between the undue influence and entry into the transaction. It does not, however, have to be the sole cause and there is no place here for anything resembling a "but for" test of causation. ${ }^{85}$ In UCB Corporate Services Ltd v Williams, ${ }^{86}$ the appellate court rejected the contention that the husband, who had fraudulently procured the consent of his wife, should be able to escape the consequences of his actions by establishing that, had his wife had the opportunity to make a free and informed choice, she would have acted in the same way. Peter Gibson LJ explained:

The fact is that the husband's fraud deprived the wife of the opportunity to make such a choice, and, as I see it, it is that fact which founds the wife's equity (as against her husband) to set aside the transaction. ${ }^{87}$

The crucial distinction between legitimate persuasion and undue influence is essentially an issue of fact for the court to determine. ${ }^{88}$ This is inevitable because as Deputy Judge James Munby noted: "It is impossible to define, and difficult even to describe, at what point influence becomes, in the eyes of the law, undue." 89 The burden of proof, not surprisingly, rests with the person alleging to be its victim - he who asserts must prove. Nevertheless, and akin to the forensic aid of res ipsa loquitur, once a prima facie case is demonstrated the evidential burden shifts to the alleged wrongdoer to rebut the allegation that the influence was undue. A prima facie case will be demonstrated where the complainant can show that trust and confidence were placed in the alleged wrongdoer and, importantly, that the transaction cries out for explanation. ${ }^{90}$ As Lord Nicholls acknowledged, "On proof of these two matters the stage is set for the court to infer that, in the absence of satisfactory explanation, the transaction can only have been procured by undue influence." 91 Hence, the court is merely drawing appropriate inferences from the primary facts proved. The evidence required to establish a prima facie case will vary according to the facts of a given case, but relevant issues may include the nature of the influence alleged, ${ }^{92}$ the relationship between

84 Ellse v Pickeford [2006] EWHC 3293 (Ch). There the claimant was not pressured or influenced in any way to sign the documentation and the claim of undue influence was rejected.

85 Hewett v First Plus Financial Group [2010] EWCA Civ 312. Briggs J explained that all that had to be shown was that the "equitable wrong committed by the abuse of confidence was part of the process by which the victim's consent to it was obtained", at [34].

86 [2002] EWCA Civ 555.

87 Ibid., at [86]. All that needs to be shown is reliance, i.e. that the influence had an impact on the thinking of the victim: Greenwood Forest Products (UK) Ltd v Roberts (unreported) 12 March 2010.

88 As Lewison J observed in Thompson v Foy [2010] 1 P \& CR 16 at [110]: "In essence the question is whether Mrs Thompson's volition was overborne by Mrs Foy; not simply whether she was persuaded by Mrs Foy that the transaction was a good idea."

89 Bank of Scotland v Bennett (1997) 1 FLR 801 at 823. He added, at 827: "At the end of the day the question of whether or not there has, in any particular case, been actual undue influence involves a value judgment."

90 Burbank Securities Ltd v Wong [2008] EWHC 552 (Ch).

91 Royal Bank of Scotland plc v Etridge (No 2) [2001] 4 All ER 449 at 459.

92 In Wallbank v Price [2007] EWHC 3001 (Ch), the unfounded allegation was that the signatory was coerced by violence into signing the documentation. 
the parties, ${ }^{93}$ any existing disabilities, ${ }^{94}$ an examination of how the "victim" normally behaved, when free of influence, ${ }^{95}$ the number of impugned transactions, ${ }^{96}$ and size of the gift. ${ }^{97}$ The overarching concern is, as Lord Nicholls stated, "the extent to which the transaction cannot readily be accounted for by the ordinary motives of ordinary persons in that relationship". 98

Accordingly, it is only when the transaction looked at as a whole cannot be explained in terms other than those of undue influence that the burden shifts. ${ }^{99}$ In some cases this will be evident, for example, when $f, 1.5 \mathrm{~m}$ of a mother's estate was signed away to her son and daughter-in-law 100 or when a great-uncle made a $£ 45,000$ gift to a great nephew. ${ }^{101}$ In other instances, an impugned transaction can be readily justified. For example, in Thompson v Foy a mother made a gift of $f^{200,000}$ to her daughter and this was found to be explicable on the basis that the daughter and her son-in-law had made substantial improvements to the mother's property. ${ }^{102}$ There are, however, other cases where the explanation for the transaction is less obvious and requires a closer examination of the facts. In Turkey $\mathrm{v}$ Awadh, an unusual transaction was entered between family members without the parties "having inquired whether it was favourable to one, favourable to the other or fair to each". ${ }^{103}$ The court took into account various factors in order to reach its determination that the transaction, curious as it may be, was explicable without there being undue influence. ${ }^{104} \mathrm{~A}$ similar stance was adopted in Greenwood Forest Products (UK) Ltd v Roberts where the onesided nature of the arrangements was explicable on the basis of the potential gains that would be generated if the project was successful. ${ }^{105}$

\section{PRESUMED UNDUE INFLUENCE}

Class 2 presumed undue influence is posited upon there being a pre-existing relationship of trust and confidence between the parties which is of such a nature that the law must assume that one party has dominance over the other. Lord Nicholls explained:

93 The fact that a marriage might be tempestuous and the wife reluctantly complies with her husband's sexual demands does not support a conclusion that she subordinates herself to her husband's financial demands: Wallbank v Price [2007] EWHC 3001 (Ch).

94 In Public Trustee v Bailey [2005] EWHC 3524 (Ch), a daughter with a mental illness was persuaded by her mother to enter into an injurious transaction. The daughter's vulnerability offered evidence that the parent had exerted actual undue influence. Similarly, in Burbank Securities Ltd v Wong [2008] EWHC 552 (Ch), the fact that the signatory suffered from cerebral palsy and an impaired cognitive function was an issue that the court took into account.

95 Hogg v Hogg [2007] EWHC 2240 (Ch).

96 In Aldridge v Turner [2004] EWHC 2768 (Ch), 62 transactions of modest sums were successfully challenged.

97 De Wind $\mathrm{v}$ Wedge [2008] EWHC 514 (Ch).

98 Royal Bank of Scotland plc v Etridge (No 2) [2001] 4 All ER 449 at 458, 459.

99 Turkey v Awadh [2005] 2 P \& CR 29.

100 Hodson v Hodson [2006] EWHC 2878 (Ch). Although rejected by the House in Etridge as having no substantive role to play, the expression "manifest disadvantage" continues to be employed as an evidential factor: see Vale v Armstrong [2004] EWHC 1160 (Ch); Macklin v Dowsett [2004] EWCA Civ 904.

101 Goodchild v Bradbury [2006] EWCA Civ 1868.

102 [2010] 1 P \& CR 16. In DeWind v Wedge [2008] EWHC 514 (Ch), a mother made a substantial gift to her son which was occasioned by him losing money in a business venture. This provided an explanation for her actions (i.e. concern for the well being of her son) independent of the alleged influence.

103 Per Chadwick LJ [2005] 2 \& CR 29 at 523.

104 See also Re Brocklehurst [1977] 3 WLR 696, where the kindness of the donor resulted from the ordinary motive of friendship.

105 (Unreported) 12 March 2010. 
The law has adopted a sternly protective attitude towards certain types of relationship in which one party acquires influence over another who is vulnerable and dependent and where, moreover, substantial gifts by the influenced or vulnerable person are not normally to be expected. ${ }^{106}$

Traditional thinking was that there were two sub-categories of presumed undue influence: Class $2 \mathrm{~A}$ and Class $2 \mathrm{~B} .{ }^{107}$ The former, as discussed below, hinges upon the pre-existence of a special relationship between the parties. The latter, now redundant, was said to arise where the complainant was able affirmatively to demonstrate the de facto existence of a relationship within which the complainant generally placed trust and confidence in the alleged wrongdoer. ${ }^{108}$

Class 2A offers a mechanistic assumption that certain formal relationships are sufficiently close to give rise to the irrebuttable presumption at law that one party has influence and dominance over the other. ${ }^{109}$ The categories of relationship that may qualify for the purposes of this forensic exercise are not closed and, hence, it is not possible to draw up an exhaustive list. ${ }^{110}$ They must expand (and possibly contract) to keep in tune with modern sensibilities. ${ }^{111}$ In $R v A G$ of England \& Wales, for example, the Privy Council assumed that the relationship between a commanding officer and soldier could be classified in this way. ${ }^{112}$ Other inclusions are such potentially imbalanced relationships as exist between parent and child, ${ }^{113}$ guardian and ward, ${ }^{114}$ solicitor and client, ${ }^{115}$ trustee and beneficiary, ${ }^{116}$ doctor and patient, ${ }^{117}$ and priest and penitent. ${ }^{118}$ The common link between these examples is that the status of the parties automatically demonstrates the requisite element of trust and confidence placed by one in the other and raises the possibility of undue influence. ${ }^{119}$

106 Royal Bank of Scotland plc v Etridge (No 2) [2001] 4 All ER 449 at 480.

107 See Bank of Credit and Commerce International SA v Aboody [1990] 1 QB 923.

108 The difference between Class 2A and Class 2B was articulated by Millett LJ in Credit Lyonnais Bank v Burch [1997] 1 All ER 144 at 154, "in the former case there is an irrebuttable presumption of law that the relationship is one of trust and confidence; in the latter this must be proved as fact".

109 Shaw v Finnimore [2009] EWHC 367 (Ch). There have, however, been calls for its abolition on the basis that the claimant should always be required to establish a de facto relationship of trust and confidence: Devenney and Chandler, "Unconscionability", n. 57 above, at 558.

110 Lord Hobhouse, in Royal Bank of Scotland plc v Etridge (No 2) [2001] 4 All ER 449 at 482, offered the general guidance that: "Typically, they are fiduciary or closely analogous relationships."

111 In Leeder v Stevens [2005] EWCA Civ 50, the Court of Appeal attempted to extend the category to fiancé and fiancée. Although there is old authority for this proposition (Re Lloyds Bank [1931] 1 Ch 289), this defies modern thinking and authority.

112 [2003] UKPC 22.

113 Lancashire Loans Ltd v Black [1934] 1 KB 380. The presumption continues to apply after the child has achieved adulthood. A child, however, is not to be taken to have ascendancy over a parent: Hogg v Hogg [2007] EWHC $2240(\mathrm{Ch})$.

114 Hylton v Hylton (1754) 2 Ves Sen 547.

115 In Markham v Karsten [2007] EWHC 1509, the solicitor and client also cohabited with one another. Briggs J held that the professional aspect of their relationship could not be ignored and suggested that it strengthened the influence which is presumed to exist. He added, at [36]: "Nor in my judgment is it correct to confine the presumption of influence, as between solicitor and client, to transactions of a legal rather than a domestic nature."

116 Benningfield v Baxter (1886) 12 App Cas 167.

117 Re CMG [1970] Ch 574.

118 Allcard v Skinner (1897) 36 Ch D 145 (undue influence of a nun by her mother superior).

119 Lord Hobhouse in Royal Bank of Scotland plc v Etridge (No 2) [2001] 4 All ER 449 at 482 described these as, "legal relationships where one party is legally presumed to repose trust and confidence in the other, the other side of the coin to the duty not to abuse that confidence". 
Significantly, the relationship between husband and wife does not fall within the category of protected relationship. ${ }^{120}$ Devenney and Chandler, however, question the value of this classification model, asking "do we have the same 'awe' of doctors today as once prevailed and is the average client so respectful of a solicitor's advice and guidance?"121 The authors make the additional point that "there is little justification in applying a 'blanket-rule' to all relationships of that type. No two relationships are exactly the same."122

Predominant thinking prior to Etridge was that the presumption relieved the complainant of the need to prove both that influence had been exerted and that it was undue. ${ }^{123}$ Lord Clyde recognised that the existence of Class $2 \mathrm{~B}$ had instilled uncertainty as to "whether the presumption is of the existence of an influence or of its quality being undue". ${ }^{124}$ Once it is accepted that all that is presumed is influence, ${ }^{125}$ Class $2 \mathrm{~B}$ became surplus to requirement. As Lord Scott observed, "it makes no sense to find, on the one hand, that there was no undue influence, but on the other that the presumption applies"126 and added: "Either the evidence did justify the finding of undue influence or it did not."127 Nevertheless, this misconception "set the law on the wrong track" 28 and doggedly continues to inhibit proper understanding of the relationship between actual and presumed undue influence. ${ }^{129}$

The extent to which presumed influence is undue remains an issue of fact and inference to be established from the evidence adduced and the nature of the transaction itself. Any alternative conclusion would mean that, say, a seasonal gift from a patient to a doctor would always be assumed to arise from undue influence exerted by the latter. ${ }^{130}$ In order to avoid such absurdity, the law must insist upon there being additional evidence before the burden of proof is reversed. As shown, there must be something about the nature of the transaction that calls for explanation, for example, that it cannot be accounted for by the ordinary motives of a patient seeking to make a seasonal gift to a doctor. ${ }^{131}$ There is no need to show that the other party has been guilty of a wrongful or dishonest act. ${ }^{132}$ If, however, the transaction does not demand explanation, the burden does not shift. In Birmingham City Councilv Forde, a litigant signed a conditional fee agreement with her solicitor

120 Royal Bank of Scotland plc v Chandra [2010] EWHC 105 (Ch). Neither does it include the relationship of aunt and nephew (Randall v Randall [2004] EWHC 2258 (Ch)), accountant and client (Mitchell v James (unreported) 10 July 2001), bank and customer (National Westminster Bank v Morgan [1985] AC 686), nor employer and employee (Credit Lyonnais Bank v Burch [1997] 1 All ER 144).

121 Devenney and Chandler, "Unconscionability", n. 57 above, at 558.

122 Ibid.

123 Bank of Credit and Commerce International SA v Aboody [1990] 1 QB 923.

124 Royal Bank of Scotland plc v Etridge (No 2) [2001] 4 All ER 449 at 477.

$125 \mathrm{R}$ v AG for England \& Wales [2003] UKPC 22. This is no new thing, however, as Cotton LJ made the same point in Allcard v Skinner (1897) 36 Ch D 145 at 171.

126 Royal Bank of Scotland plc v Etridge (No 2) [2001] 4 All ER 449 at 513.

127 Ibid., at 523. Lord Hobhouse could not see why the proof of a de facto relationship should activate, "some artificial legal presumption" (at 483).

128 Per Lord Scott in Royal Bank of Scotland plc v Etridge (No 2) [2001] 4 All ER 449 at 502.

129 Greenwood Forest Products (UK) Ltd v Roberts (unreported) 12 March 2010; Randall v Randall [2004] EWHC 2258 (Ch).

130 In the words of Lord Nicholls in Royal Bank of Scotland plc v Etridge (No 2) [2001] 4 All ER 449 at 461: "Such a presumption would be too far-reaching... The law would rightly be open to ridicule, for transactions such as these are unexceptionable. They do not suggest that something may be amiss."

131 Clare v Joseph [1907] 2 KB 369.

132 Niersmans v Pesticcio [2004] EWCA Civ 372. 
which contained a success fee. ${ }^{133}$ Rejecting an attempt to have the agreement set aside on the basis of undue influence by the solicitor, Clarke J explained that:

Many people would regard it as unacceptable that [the solicitors] should get nothing for their work. The ordinary motives of ordinary persons do not exclude doing the decent thing, even if some persons would not be minded to do so. ${ }^{134}$

\section{Putting the lender on inquiry}

The lender is not under any positive legal duty to make inquiries. Indeed, to require this would amount to what Sir Richard Scott VC called, "unwarrantable impertinence on the bank's part". ${ }^{135}$ He emphasised:

A bank has no business inquiring into the personal relationship between those with whom it has business dealings or as to their personal motives for wanting to help one another. A bank is not to be treated as a branch of the social services agencies. ${ }^{136}$

Nevertheless, the notion of the lender being "put on inquiry" lies at the heart of the O'Brien defence. It is, as Lord Hobhouse put it, "[the] additional factor before the lender's conscience is affected and he is to be restrained from enforcing his legal rights". ${ }^{137}$ In general terms, this barrier is overcome whenever one party agrees to stand as surety for the debts of another. The undemanding nature of this test is obviously designed to assist a claimant, ${ }^{138}$ but it also offers protection for the creditor in that, "it assists banks to put in place procedures which do not require an exercise of judgment by their officials". ${ }^{139}$ The underlying thesis of this requirement is that, if the transaction is not on its face to the advantage of the surety, there is a real risk that the principal debtor acted improperly in procuring the guarantee. Hence, the lender should be put on inquiry that the surety may not fully understand the transaction or may not be acting with a free will.

As to whether the lender is or is not put on inquiry hinges upon the facts as known to the lender or its agent. In Burbank Securities Ltd v Wong, ${ }^{140}$ the knowledge of a mortgage broker acting for the surety was attributed to the lender. Hodge J explained:

If this were not the case, then banks and other financial institutions could readily avoid the need to take the sensible steps to minimize the commission of equitable wrongs against their customers . . . by the simple expedient of inviting applications for finance only from intermediates appointed by their customers rather from their customers direct. ${ }^{141}$

In the normal course of events, it will be apparent when one party is acting as the surety for another. Lord Hobhouse acknowledged: "The bank should know who the principal debtor is and what is the purpose of the facility." 142 This entails that the lender need not adopt the role of a private investigator and has no need to survey beyond the face of the credit documentation. The requirement is simply that the disadvantageous nature of the

133 [2009] EWHC 12 (QB).

134 Ibid., at [106].

135 Banco Exterior Internacional SA v Thomas [1997] 1 All ER 46 at 55.

136 Ibid.

137 Royal Bank of Scotland plc v Etridge (No 2) [2001] 4 All ER 449 at 483, 484.

138 As Lord Nicholls observed in Royal Bank of Scotland plc v Etridge (No 2) [2001] 4 All ER 449 at 466: "The test should be simple and clear and easy to apply in a wide range of circumstances."

139 Per Lord Hobhouse in Royal Bank of Scotland plc v Etridge (No 2) [2001] 4 All ER 449 at 484.

140 [2008] EWHC 552.

141 Ibid., at [35].

142 Royal Bank of Scotland plc v Etridge (No 2) [2001] 4 All ER 449 at 484. 
transaction for the surety would be obvious to an independent and reasonable person who perused the relevant forms. ${ }^{143}$ From this perspective, it is the lender's belief as to how the money is to be used which is crucial and not how in actual fact the funds are deployed. ${ }^{144}$ There is some authority to suggest that this rule gives way when the outward appearance of the transaction suggests a surety relationship, but the money is actually used for the joint benefit of the parties. ${ }^{145}$ Neill LJ felt that the true purpose was the redemption of earlier mortgages, but the stated purpose was to finance a business expansion. In circumstances where only a small fraction of the monies were employed for the stated purpose, he felt the correct approach was to consider what would have been the position had the lender been alerted to how the monies were really intended to be applied. He concluded that the lender was entitled to treat the transaction as an ordinary business transaction. While this embodies an unusual twist of legal reasoning, instinctively it is to be viewed as correct. If it were otherwise, the wife would have been able to set aside a transaction that was to her benefit and which, had the true reason been disclosed, would not have put the bank on inquiry.

Returning to more conventional territory, if the expressed purpose of the transaction is, say, to discharge an existing mortgage and to buy a family holiday home for the husband and wife then, generally, there is nothing to arouse the suspicions of the lender. ${ }^{146}$ Similarly, the lender's suspicions are not aroused where the joint charge is to guarantee a loan for a business that is operated jointly by the parties, ${ }^{147}$ or where the debtor is a joint venture company and the surety is one of the three shareholders ("partners"). ${ }^{148}$ In Burbank Securities Ltd v Wong, ${ }^{149}$ however, the lender should have doubted the veracity of the stated purpose. The lender was told that the surety was a business partner and that the money was for a joint business venture. Nevertheless, there were inconsistent claims and the lender knew that the surety was in receipt of social security payments. It was also evident, due to her medical condition, that she could not command a senior position within a company. When spoken to on the telephone, moreover, the surety merely answered "yes" to the lender's questions.

The justification for treating a genuine joint advance differently from a surety case is, as Lord Browne-Wilkinson explained in CIBC Mortgages plc v Pitt:

in the latter, there is not only the possibility of undue influence having been exercised but also the increased risk of it having in fact been exercised because, at least on its face, the guarantee by a wife of her husband's debts is not for her financial benefit. ${ }^{150}$

In determining which side of the line a transaction falls, no regard is had to the argument that a surety wife will potentially derive benefit if her husband's business succeeds. 151 Difficulties have, however, arisen where the nature of the transaction is less clear-cut and when the transaction is only in part to the benefit of the surety. For example, when a wife agrees to the transaction in order to secure funds to discharge the debt of a company in

143 Mahoney v Purnell [1996] 3 All ER 61.

144 Chater v Mortgage Agency Services (No 2) Ltd [2004] P \& CR 4.

145 Hedworth v Scotlife Home Loans (No 2) Ltd (unreported) 15 May 1995.

146 Leggatt v National Westminster Bank (2001) P \& CR 432. There, it was plainly to the advantage of the surety wife to take a later charge (as to which she was not independently advised) to replace an earlier one that she had undertaken following legal advice.

147 Equity \& Law Life Assurance Society plc v McGrath (unreported) 9 May 1995.

148 Bank of Scotland v Makris (unreported) 15 May 2009.

149 [2008] EWHC 532 (Ch),

150 [1993] 4 All ER 433 at 441.

151 Midland Bank. v Greene [1994] 2 FLR 827. 
relation to which she and her husband are shareholders. Until the decision in Etridge, it was necessary for the court to embark upon an investigation as to whether the transaction, when looked at as a whole, was in substance a surety transaction. ${ }^{152}$ If it was not, there was nothing to put the bank on inquiry. Conversely, if the wife's interest was nominal then, as the potential risks significantly outweighed the possible gains, the creditor's suspicions should be aroused. ${ }^{153}$ This particular forensic exercise has, seemingly, become otiose postEtridge. Lord Nicholls explained in the context of a company run jointly by the parties:

Her shareholding may be nominal, or she may have a minority shareholding or an equal shareholding with her husband. In my view the bank is put on inquiry, even when the wife is a director or secretary of the company. Such cases cannot be equated with joint loans. The shareholding interests, and the identity of the directors, are not a reliable guide to the identity of the persons who actually have the conduct of the company's business. ${ }^{154}$

\section{The role of constructive notice}

In these surety cases, the doctrine of notice operates in a fashion subtly different from its conventional form. Lord Scott explained:

the constructive notice that is sought to be attributed to the bank is not constructive notice of any pre-existing right or prior equity of the wife ... It is the notice that the bank has of the impropriety that creates the wife's right to set aside the transaction. The wife does not have any prior right or prior equity. ${ }^{155}$

Accordingly, in this context the doctrine of notice offers more than a defence of the purchaser against the adverse claims of third parties, it is a constituent feature of the very right that the surety has to establish. Hence, if the creditor has constructive notice of the wrongdoing, the victim is entitled to have the transaction set aside. ${ }^{156}$ The onus, however, rests on the surety to prove affirmatively that the transaction is one that puts the bank on inquiry and to establish that it is tainted by the wrongdoing of a third party. Most certainly it is not for the lender to prove the negative for, as Lord Hoffmann explained in Barclays Bank plc $\mathrm{v}$ Boulter:

a rule which generally put the burden upon the bank to show that it had no notice of vitiating circumstances could operate very unreasonably. It would mean that even when the relationship between the parties, as known to the bank, gave rise to no apparent risk of undue influence, the bank would have to prove that it had no notice of any which may in fact have been exercised. ${ }^{157}$

It has never been doubted that, where undue influence has been applied, the entire transaction is voidable. ${ }^{158}$ Some uncertainty arose, however, in the context of

152 Allied Irish Bank v Byrne [1995] 2 FLR 325.

153 Goode Durrant Administration v Biddulph [1994] 2 FLR 551.

154 Royal Bank of Scotland plc v Etridge (No 2) [2001] 4 All ER 449 at 466. The attempt by Lord Nicholls was, as Deputy Judge David Donaldson put it in Bank of Scotland v Makris (unreported) 15 May 2009 at [49], "to create a single and clear bright line of division between those cases which required a bank to insist on the guarantor receiving independent legal advice and those which did not".

155 Royal Bank of Scotland plc v Etridge (No 2) [2001] 4 All ER 449 at 499.

156 In the wake of Yorksbire Bank plc v Tinsley [2004] 3 All ER 463, a substitute mortgage with the same mortgagee can be vitiated where the original mortgage was legally ineffective on O'Brien principles. This is so even if the second transaction was not induced by any equitable wrongdoing. Of course, this cannot apply if the second transaction is with a different mortgagee.

157 (1999) 4 All ER 513 at 519.

158 Barclays Bank v O’Brien [1993] 4 All ER 417. 
misrepresentation as to the extent of liability. In Bank Melli Iran v Samadi-Rad, ${ }^{159}$ the issue raised was whether a transaction involving an indebtedness of $f 1.2 \mathrm{~m}$ should be upheld in part so as to accord with the misrepresentation. It would then follow that the surety would remain bound to the misrepresented financial ceiling $(£, 140,000)$ with the excess amount being irrecoverable. Although this line of reasoning had appealed to the lower court, the Court of Appeal regarded it as unsound. It is now beyond argument that the surety's remedy is an all-or-nothing affair. ${ }^{160}$ This is logical in that the surety might not have offered any guarantee whatsoever if the true extent of financial liability had been known. Consequently, the lender's charge will not be enforceable against the beneficial interest of the victim, but remains enforceable against the property interest (if any) of the wrongdoer.

Much of the litigation concerning the O'Brien defence has concerned the steps that the lender must take in order to avoid being affixed with constructive notice and to overcome the surety's defence. It is totally unrealistic to expect the lender specifically to ask of a surety whether there has been undue influence exerted or some other wrongdoing perpetrated. Indeed, as Lord Nicholls put it: "This is not a step that the banks should be expected to take." 161 This entails that the lender will seldom acquire any actual notice of wrongdoing. Similarly, there will rarely be any relationship of agent and principal between wrongdoer and lender that could impute notice of misfeasance to the latter. Once put on inquiry, therefore, the lender must proceed on the assumption that the surety may not fully understand the full contractual obligations arising from the legal charge. This is in recognition of the complexity of the printed documentation employed and the consequence that, "it is unlikely to be read let alone understood by private guarantors who lack legal training or appropriate business experience". ${ }^{162}$ The most that can be expected of the lender, therefore, is to make sure that the surety understands the liabilities incurred and the implications of the transaction. ${ }^{163}$ Undoubtedly, this is best achieved by means of a personal interview with the surety where the transaction can be explained and the surety advised to have recourse to independent legal advice. If communication occurs via correspondence there is always the risk that letters will be intercepted and never reach the intended recipient. ${ }^{164}$ Nevertheless, lenders tend to eschew private meetings and, understandably, prefer to shelter behind the skirts of the independent legal advisor. ${ }^{165}$ This tactic also avoids the threat of additional liability that would arise if the lender's representative failed to explain properly the proposed transaction. From this perspective it is not unreasonable for the lender to transfer responsibility to an independent legal advisor. ${ }^{166}$ Usually, this will ensure that the lender is able to defeat the claims of a wronged surety. ${ }^{167}$ Nevertheless, the established practice was viewed with unease by the House in Etridge because lenders, as Lord Hobhouse lamented:

were not doing anything themselves. They were instructing a solicitor, asking him to supply a formal certificate limited to comprehension and that is all. This is

159 [1995] 2 FLR 367.

160 See also TSB v Camfield [1995] 1 All ER 951.

161 Royal Bank of Scotland plc v Etridge (No 2) [2001] 4 All ER 449 at 467.

162 Per Lord Hobhouse in Royal Bank of Scotland plc v Etridge (No 2) [2001] 4 All ER 449 at 485.

163 As Lord Nicholls observed in Royal Bank of Scotland plc v Etridge (No 2) [2001] 4 All ER 449 at 476 : "As a measure of protection this is valuable. But, in all conscience, it is a modest burden for banks and other lenders."

164 As occurred in Abbey National Bank plc v Stringer [2006] EWCA Civ 338 (a son intercepting his mother's correspondence).

165 In Burbank Securities Ltd v Wong [2008] EWHC 552, the lender met with the surety and, as a result, should have appreciated that she was the subject of undue influence.

166 A solicitor or, as in Barclays Bank plc v Coleman (2000) 1 All ER 385, a legal executive.

167 Bank of Scotland v Hill [2002] EWCA Civ 1081. 
what had given rise to the fiction of free and informed consent where none existed and no steps had been taken to discover the true position. ${ }^{168}$

While acknowledging that lenders should not be obliged to provide the advice personally, the House put in place new procedures and safeguards. These are designed to ensure that "the fiction of independent advice and consent should be replaced by true independent advice and real consent". 169

While the lender is still not expected to advise the surety as to the nature of the transaction, post-Etridge, the creditor must engage in some form of direct contact with the surety. This was felt necessary because the surety often becomes involved with the transaction at a late stage and this tendency operated to deprive the surety of a choice of advisor and to obscure the reason why the advice was being offered. The lender is required to communicate certain information to the surety as to why independent legal advice is required. The surety should be told that the purpose of the requirement is to protect the lender in that thereafter the surety will be legally bound by the transaction. The surety should also be invited to nominate a solicitor who is to act on the surety's behalf ${ }^{170}$ and subsequently provide confirmation to the lender that the transaction had been explained. The lender is then expected to put the transaction on hold until it has received an appropriate response directly from the surety. These modest steps forward mark a major improvement. The new regime, as Lord Hobhouse put it:

is a far cry from the situation which has been tolerated in the past where the wife has not appreciated that she had any solicitor or was being advised and did not know the existence of the certificate or its significance; indeed, it has been that type of situation which has given rise to the most scandalous cases. ${ }^{171}$

Change has also occurred as regards the information to be provided by the lender to the surety's advisor. As the lender will usually have a greater insight into the principal debtor's financial standing than that of the advisor, it is thought reasonable for the lender to furnish this information. Although the precise information to be given is fact sensitive, the House did offer general guidance. It was felt that the lender should provide details as to the stated purpose of the loan, the current amount of the principal debtor's existing indebtedness, any extant overdraft facility and the amount and terms of any new facility. A copy of the loan application form is also to be forwarded to the advisor. Of course, in order to avoid a breach of confidence, the lender will have to obtain the consent of the principal debtor to such disclosures, but this is easily achieved if the consent is made a condition of the proposed transaction. ${ }^{172}$ Although this will rarely be the case, particularly if lender and surety never engage in a face-to-face meeting, if the lender suspects that there is some wrongdoing afoot then the lender is under an obligation to report this suspicion to the surety's advisor. Due to the vagaries of the postal system, the lender should always obtain confirmation that the documentation was actually received by the advisor.

168 Royal Bank of Scotland plc v Etridge (No 2) [2001] 4 All ER 449 at 489.

169 Per Lord Hobhouse in Royal Bank of Scotland plc v Etridge (No 2) [2001] 4 All ER 449 at 489.

170 Although this may be the same solicitor as is acting for the principal debtor, the surety should be asked whether a different solicitor would be preferable.

171 Royal Bank of Scotland plc v Etridge (No 2) [2001] 4 All ER 449 at 488.

172 Understandably, the lender cannot rely on the principal borrower to furnish this type of information: National Westminster Bank plc v Kostopolos (2000) 1 FLR 815. 


\section{The emphasis upon independent advice}

Experience has shown that pre-Etridge the advice provided to the surety was often perfunctory and, thereby, undermined the safeguard that it was intended to secure. A graphic example of this occurred in Lloyds Bank plc $\mathrm{v}$ Wright-Bailey ${ }^{173}$ where the extent of an impatient solicitor's advice was:

What this document means is that if your husband fails to pay back the Bank, you will be held responsible and the bank will seek recovery from you and can sell your home.

Clearly, something was required to improve the quality and efficacy of independent advice. In Lord Clyde's words, "the wife's consultation with her solicitor is a serious step which is not to be brushed off as a mere formality or a charade". ${ }^{174}$ Not surprisingly, therefore, the House felt it necessary to recast the role of the independent advisor.

First, it was accepted that the scope of the independent advisor's professional responsibilities is geared to what the advisor is retained to do by the surety, that is, to bring home the risk of the transaction. If the advisor is not instructed by the surety, but is instead instructed by the lender, ${ }^{175}$ the latter cannot rely on a solicitor's inaccurate confirmation that the transaction has been explained. ${ }^{176}$ Although the validity of transactions should not turn upon fine distinctions in the wording of the instructions given to solicitors (or, indeed, the certificates that they give), ${ }^{177}$ the retainer must impress upon the advisor the importance of giving the surety sufficient advice about the legal implications and effect of the proposed transaction. ${ }^{178}$ This will require the advisor to have a face-to-face meeting with the surety and to explain, in straightforward language, the purpose of the consultation and that the lender will rely on the advice given so as to counter any later allegation of wrongdoing. This meeting should (but strictly need not) ${ }^{179}$ occur in the absence of the principal debtor for, as Lord Hobhouse acknowledged:

if the purpose is to satisfy oneself that the wife is acting freely in the knowledge of the true facts, an interview in the presence of the husband is unlikely to achieve this objective if she has been improperly influenced by him. ${ }^{180}$

Obviously, there is some overlap with the information previously imparted to the surety by the lender, but it does offer a safety net for a surety whose correspondence from the lender may have been intercepted by an unscrupulous principal debtor. Unless the circumstances are exceptional, ${ }^{181}$ the advisor is expected not to abort the transaction by refusing to confirm that the transaction has been explained. As Lord Nicholls emphasised, "at the end of the day the decision on whether to proceed is the decision of the client, not

173 (Unreported) 3 May 1995.

174 Royal Bank of Scotland plc v Etridge (No 2) [2001] 4 All ER 449 at 479.

175 For the purposes of this classification, it matters not who actually pays the solicitor's fees: Banco Exterior Internacional v Mann [1995] 1 All ER 936.

176 In National Westminster Bank plc v Amin [2002] 1 FLR 735, the only instructions given to the advisor were provided by the lender and the surety never gave the solicitor authority to inform the bank as to what had transpired during the interview.

177 Leggatt v National Westminster Bank (2001) P \& CR 432.

178 National Westminster Bank plc v Amin [2002] 1 FLR 735. There the bank asked the solicitor merely to attend to "the formalities" which Lord Scott felt was totally inapt.

179 National Westminster Bank plc v Amin [2002] 1 FLR 735.

180 Royal Bank of Scotland plc v Etridge (No 2) [2001] 4 All ER 449 at 486.

181 That is "where it is glaringly obvious that the wife is being grievously wronged", per Lord Nicholls Royal Bank of Scotland plc v Etridge (No 2) [2001] 4 All ER 449 at 469. 
the solicitor". ${ }^{182}$ Accordingly, a lender can rely on the advisor's certification even though the advisor finds the transaction unwise and imprudent. ${ }^{183}$

Secondly, the advice provided must embrace what are labelled "the core minimum issues". Lord Nicholls felt obliged to offer general guidance because of a manifest failure by solicitors to appreciate what was required in these surety cases. A typical checklist of factors to be covered during the interview will now include an explanation of the loan documentation and associated legal consequences. The advisor must also disclose the details of the proposed transaction and these will include the purpose of the loan, its amount and terms and whether it can be increased without the surety being notified. In addition, the advisor should ascertain from the surety the current value of the property to be charged and whether there are any other assets available from which repayment could be made if the loan was enforced. In the light of the financial information that should have been supplied by the lender, there should also be some discussion of the principal debtor's existing debts and current overdraft facility. Absent this confidential information, the advisor should decline to provide certification that the transaction has been explained. The surety is, moreover, to be informed that withdrawal from the proposed transaction is still possible and that the advisor can open negotiations for a change of terms (e.g. to achieve a lower limit on the surety's liabilities). The advisor must not, however, provide any certification to the lender without the express authorisation of the surety. This neatly sidesteps potential problems, as experienced in the Amin case, as to whether or not the solicitor is retained by the surety. By providing this list of key considerations to be addressed, the House has ensured that the advice is now more rigorous and structured than it was before and that a sketchy outline of potential liability will no longer suffice.

Thirdly, the allusion to the "independent" advisor has traditionally raised doubt as to whether the solicitor must act solely for the surety. In many surety cases, the solicitor advising the surety will also represent the principal debtor either in the particular transaction or generally. The House in Etridge, therefore, recognised that "a simple and clear rule is needed, preferably of well-nigh universal application". ${ }^{184}$ Although there may be advantages associated with seeking out a totally independent advisor (e.g. the surety may be less inhibited and the advisor more focused), separate representation is not to be insisted upon. ${ }^{185}$ The solicitor's advice is not tainted merely because the advisor happens also to represent the interests of the principal debtor. Lord Nicholls explained:

When accepting instructions to advise the wife the solicitor assumes responsibilities directly to her, both at law and professionally. These duties, and this is central to the reasoning on this point, are owed to the wife alone. He is concerned only with her interests. ${ }^{186}$

Hence, by accepting the surety's retainer, the advisor offers the assurance to the surety that the advice is to be given impartially, fully and competently. ${ }^{187}$

Finally, if the solicitor fails to advise the surety properly then the client can issue proceedings for breach of contract or under the law of negligence. Admittedly, this does

182 Royal Bank of Scotland plc v Etridge (No 2) [2001] 4 All ER 449 at 469. He continued: "A wife is not to be precluded from entering into a financially unwise transaction if, for her own reasons, she wishes to do so."

183 Absent certification, the lender cannot assume that the advice has been provided: Bank of Ireland $\mathrm{v}$ Cox (unreported) 19 July 1995.

184 Per Lord Nicholls in Royal Bank of Scotland plc v Etridge (No 2) [2001] 4 All ER 449 at 471.

185 Banco Exterior Internationalv Mann [1995] 1 All ER 936.

186 Royal Bank of Scotland plc v Etridge (No 2) [2001] 4 All ER 449 at 472.

187 Bank of Scotland v Bennett [1999] 1 FLR 1115. 
little to maintain a roof over the surety's head because the lender will usually continue to be shielded behind the advisor's certification that the transaction had been explained. The general rule is that the bank can rely upon the professional integrity and competence of the solicitor and it is not for the bank to form a view as to whether the solicitor has a conflict of interest. ${ }^{188}$ As Ogilvie puts it:

Subsequent solicitor-spouse issues would not invalidate the bank's security vis-àvis the surety. A borrower would be free to exercise undue influence, actual or presumed, but with the certificate and the surety's signature, that conduct would be irrelevant to the bank's right to enforce the security. A largely formal legal test obviates the need to investigate any personal relational messiness. ${ }^{189}$

A road less travelled concerns the circumstances in which the sins of the solicitor will be visited upon the lender. Broadly put, this will occur when the lender either knows or ought to know that appropriate advice has not been delivered. The overarching need is for the lender to have taken reasonable steps to ensure that the nature and risks of the transaction are brought home to the surety. As Blackburne J observed in First National Bank plc $\mathrm{v}$ Achampong:

[the bank] must have proper grounds for thinking that the solicitor has advised her on the risks she runs from entering into the transaction whether or not, in fact, the solicitor has properly discharged his duty to her. ${ }^{190}$

It is to be remembered that such knowledge is not acquired merely because the advisor acts both for the lender and for the surety. ${ }^{191}$ As discussed earlier, in such circumstances the advisor is not to be regarded as acting as the agent of the former and, hence, knowledge of any deficiency in the advice given is not to be imputed to the lender. ${ }^{192}$ A different outcome might arise, however, where the surety visits the lender's solicitor (e.g. for a signature to be witnessed), but never retains the solicitor to provide advice on the transaction. According to Lord Scott, as the advisor would then be instructed by the lender alone, the bank would have imputed notice of the lack of advice if certification to the contrary was mistakenly issued by the advisor. ${ }^{193}$ Similarly, the lender may be affixed with notice due to the onerous or strange nature of the transaction in hand. ${ }^{194}$ In Credit Lyonnais Bank v Burch, ${ }^{195}$ the transaction was regarded by Millett LJ as being so unduly onerous and extreme that the lender must have known that no competent solicitor could advise the

188 Bank of Baroda v Rayarel [1995] 2 FLR 376.

189 MH Ogilvie, "The reception of Etridge (No 2) in Canada" (2008) JBL 191, at 201. Of course, if there is no certification provided by the advisor, the lender proceeds at its own peril: Cooke v National Westminster Bank plc (1998) The Times, 27 July.

190 [2003] EWCA Civ 487 at [33].

191 Barclays Bank plc v Thomson (1997) 4 All ER 826.

192 As Lord Nicholls emphasised in Royal Bank of Scotland plc v Etridge (No 2) [2001] 4 All ER 449 at 472 : "To impute to the bank knowledge of what passed between the solicitor and the wife would contradict the essential feature of the relationship. The mere fact that, for its own purposes, the bank asked the solicitor to advise the wife does not make the solicitor the bank's agent in giving that advice."

193 Royal Bank of Scotland plc v Etridge (No 2) [2001] 4 All ER 449 at 507. He repeated this view in National Westminster Bank plc v Amin [2002] 1 FLR 735 at 740, 741: "Who gave the solicitors the instructions under which he was acting? If the answer is 'the bank', then the bank, it seems to me, cannot rely on the solicitor's inaccurate confirmation."

194 See Zamet v Hyman [1961] 1 WLR 1442.

195 [1997] 1 All ER 144. 
surety to enter it. ${ }^{196}$ By way of obiter, he concluded that, even if the surety had received independent advice, the lender would have been bound by her equity. ${ }^{197}$ In the Etridge case, Lord Hobhouse expressed a similar sentiment when, in the context of a wife shackled to an all monies, unlimited charge, questioned, "how can it be if the wife has in truth been independently advised"? 198 Knowledge can also be readily attributed in circumstances where the lender has not supplied the necessary information to the advisor, say, as to the principal debtor's financial standing. ${ }^{199}$ Due to this omission, the lender will either know or ought to know that, despite certification to the contrary, the advisor could not have fully explained the transaction to the surety. ${ }^{200}$ This possibility was accepted in National Westminster Bank plc v Amin ${ }^{201}$ where the surety (Mrs Amin) did not speak English and the advisor provided the explanation without the assistance of an interpreter. The House of Lords felt that, if the lender had known that the surety spoke only Urdu, it should have informed the advisor of this special feature. A failure to alert the advisor to the surety's vulnerability would prevent the lender from relying on the certification of the advisor that the transaction had been explained. This is because of the greater risk of undue influence and the danger that the surety might not comprehend the advice proffered. A further illustration emerges from National Westminster Bank, plc $\mathrm{v}$ Breeds. ${ }^{202}$ There the bank knew that the advisor was also the secretary of the company run by the husband and that the company was in desperate need of a cash injection. This insider knowledge entailed that it was not an ordinary type of case and alerted the bank to the strong probability of a real conflict of interest and prevented the lender from relying upon the advisor's confirmation that the transaction had been fully explained. ${ }^{203}$

\section{Conclusion}

The overhaul of the law of undue influence is to be welcomed. The reform heralded by the House of Lords in the Etridge case is much more that a mere re-branding exercise. The fundamental rethinking promoted as to the burden of proof and, in particular, the abandonment of Class 2B was intended to underscore that the classification of influence as being undue turns upon factual inferences drawn from the evidence adduced. The change in language and emphasis does not disadvantage the surety. Indeed, the ambition is to enable the surety more effectively to establish that wrongdoing has occurred. Once it is established that there is a relationship of trust and confidence and that the transaction calls out for explanation, the burden of proof shifts from the surety to the wrongdoer. The latter must then establish that the transaction is untainted. It is, therefore, ironic that the perpetuation of old and discredited wisdoms continues to afford a barrier to the ready

196 The transaction gave rise to grave suspicion, shocked the conscience of the court and cried out for explanation. Indeed, Nourse LJ felt it was arguable that Ms Burch could have had the transaction set aside as an unconscionable bargain. For an account of the relationship between unconscionable bargains and undue influence, see Devenney and Chandler, "Unconscionability", n. 57 above.

197 See also Claughton v Price (1998) 30 HLR 396 where, admittedly in the context of a bilateral transaction, Nourse LJ viewed aspects of the contract as so irrational that no solicitor could have advised the victim to sign it.

198 Royal Bank of Scotland plc v Etridge (No 2) [2001] 4 All ER 449 at 486.

199 An immaterial inaccuracy in the information provided to the advisor should not have this effect: Leggatt $\mathrm{v}$ National Westminster Bank (2001) P \& CR 432.

200 Bank of Scotland v Bennett [1997] 1 FLR 801.

201 [2002] 1 FLR 735.

202 (2001) Lloyds Rep Bank 98.

203 In Bank of Scotland v Bennett [2002] 1 FLR 735, the lender knew that the transaction was of a special and peculiar nature and materially different in significant ways from what a surety would normally encounter. 
understanding of the contemporary role and operation of these forensic aids. ${ }^{204}$ It appears that, despite the ambitious reformulation undertaken, the true import of Etridge is yet to be widely and fully understood. ${ }^{205}$

From the most obscure of origins, the jurisdiction to relieve sureties against the otherwise legitimate claims of creditors has been fashioned and refined incrementally by the courts. Its modern manifestation, which imposes responsibility on the lender to take steps to ensure that the surety is aware of the true nature of the transaction and associated legal perils, achieves a fair balance between the interests of the creditor and those of the surety. It is activated only in circumstances where the lender should be alert to the possibility of wrongdoing and where such misfeasance has, in fact, been perpetrated. The resultant emphasis lies with a series of warnings and explanations to be given by the lender and the surety's advisor. In this context, it must follow that if the prescribed steps are not taken, the lender will be affixed with constructive notice of the wrongdoing and the surety able to mount a successful defence to the lender's claims. ${ }^{206}$ If, however, the lender discharges its obligations to the surety then, in the normal course of events, it will be shielded from any future claims. Understandably, this protection is denied to a lender who either knew or should have known that the transaction has not been properly explained and understood. The ultimate safeguard for the surety is that, at the least, there will be transmitted a full explanation of the nature of the transaction and its consequences. Of course, while this should offer an antidote to misrepresentation, it can offer no guaranteed counterweight to undue influence. Indeed, as Lord Nicholls conceded: "Short of prohibiting this type of suretyship transaction altogether, there is no way of achieving that result, desirable although it is." 207 Undeniably, the workings of the O'Brien compromise now represent sound principle and offer pragmatic solutions. Unfortunately, there will always be hard cases that lie at the boundaries and highlight inadequacies in whatever test is employed. Nevertheless, the judiciary has consistently demonstrated a preparedness to adapt and modify the law so as to reduce the possibility of injustice. It is too easily overlooked that, despite any imbalance of economic might, the lender is also a victim of the wrongdoing. While the bank and the surety have conflicting interests, they both share a common interest in ensuring that the surety does not enter the transaction without informed consent and subject to undue influence. There is, surely, nothing more that should be expected of the lender.

204 See, for example, MP Thompson, "Wives, sureties and banks" (2002) Conv 174, at 181 and 182.

205 See Ogilvie, "The reception of Etridge (No 2) in Canada", n. 189 above.

206 See Burbank Securities Ltd v Wong [2008] EWHC 552 (Ch) where the lender shut its eyes to the risk that undue influence had been exerted.

207 Royal Bank of Scotland plc v Etridge (No 2) [2001] 4 All ER 449 at 464. 